\title{
Legitimacy and Criminal Justice ${ }^{\dagger}$
}

\author{
INTRODUCTION
}

\section{Jeffrey Fagan ${ }^{*}$}

\section{CRIMINAL JUSTICE, LAW AND LEGITIMACY}

Surveys of public opinion over four decades consistently show that Americans have little confidence in the fairness or effectiveness of the criminal justice system and criminal law more generally. ${ }^{1}$ This crisis of confidence is most acute among racial minorities: surveys show that more than one in three Whites have little confidence in the police, compared to more than half of Black respondents. ${ }^{2}$ Both the lack of confidence and the racial breach in perceptions of the law and legal actors have persisted for nearly four decades, regardless of whether crime was rising or falling. ${ }^{3}$

But we might reasonably ask whether and why this matters. Why should we care about how people feel about the criminal law when it affects so few of us? After all, most people have little contact with the criminal justice system, and among those with contact, more than half involved traffic stops. ${ }^{4}$ Very few of us

$\dagger$ Thanks to the Russell Sage Foundation for generous support for Working Group on Legitimacy and Criminal Justice. Members of the Working Group include Anthony Braga, Jeffrey Fagan, Tracey Meares, Robert Sampson, Tom Tyler, and Christopher Winship. Thanks to Shelby Schwartz for excellent research assistance.

* Professor of Law and Public Health, Columbia University; Director, Center on Crime, Community and Law, Columbia Law School.

1 See, e.g., Howard Schuman ET al., Racial attTudes In AmErica: Trends and INTERPRETATIONS (Rev. ed. 2007); RONALD WEITZER \& STEPHEN A. TUCH, RACE AND POLICING IN AMERICA: CONFLICT AND REFORM (2006); Lawrence D. Bobo \& Devon Johnson, A Taste for Punishment: Black and White Americans' Views on the Death Penalty and the War on Drugs, 1 Du BOIS REV. 151 (2004).

2 Bureau of Just. Stat., Sourcebook of Criminal Justice Statistics 119 (1996), available at http://www.albany.edu/sourcebook/pdf/sb1996/sb1996-section2.pdf [hereinafter SOURCEBOOK OF CRIMINAL JUSTICE STATISTICS].

3 The KeRNER REPORT: THE 1968 REPORT OF THE NATIONAL ADVISORY COMMISSION ON CIVIL DISORDERS (1988).

4 Mathew R. Durose, Erika L. Smith \& Patrick A. Langan, U.S. Dep'T of Just., CONTACTS BETWEEN POLICE AND THE PUBliC, 2005, at 1 (2007), available at http://www.ojp.usdoj.gov/bjs/pub/pdf/cpp05.pdf (reporting that fewer than one in five U.S. residents age 16 or older had a face-to-face contact with a police officer in 2005 , a decrease from $21 \%$ of residents who had contact with police in 2002). 
are victims of crime and seek police protection or redress from the courts. ${ }^{5}$ Even if citizens think the criminal law and its institutions are working poorly, casual observers can dismiss these negative views by pointing to America's generally orderly society whose crime rates (except homicide) are not much higher than other industrialized nations. ${ }^{6}$

Nevertheless, there are important reasons to listen carefully to the persistent popular disquiet about the law. In high crime eras, public concerns are linked directly to crime. But these concerns persist even in low crime eras. Accordingly, public dissatisfaction is broader in scope and widely shared. Americans are persistently frustrated with the low quality of criminal justice as a public service, chronically dissatisfied with the capacity of legal institutions to exact retribution from offenders and expressively condemn crime, and many are morally concerned about racial disparities in the administration of criminal justice. ${ }^{7}$ This dissatisfaction with the criminal justice system is a constant force, churning and undermining confidence in legal institutions and destabilizing political equanimity in a way that keeps crime politically "in play" even in low crime periods. The disquiet threatens to erode the public perception that the criminal law and legal institutions are legitimate and raises the prospect of disengagement of citizens from the important collaborations that are essential to the co-production of security. ${ }^{8}$

The modern crisis of legitimacy in American criminal justice spans three dimensions of the functions of justice that produce legitimacy: concerns about procedural fairness and respectful treatment that recognizes citizen rights and treats people with dignity, problems in the perception of distributive justice and the proportionality and consistency of legal responses to condemnable behaviors, and doubts about the capacity and the criminal law and criminal legal institutions to

5 Shannan M. Catalano, U.S. Dep't of Just., Criminal Victimization, 2005 (2006), available at http://www.ojp.usdoj.gov/bjs/pub/pdf/cv05.pdf (reporting that $2.1 \%$ of persons ages 12 or over were victims of a violent crime in 2005 , and $15.4 \%$ were victims of a property crime in the same year).

6 Franklin E. Zimring \& Gordon hawkins, Crime Is Not the Problem: lethal Violence IN AMERICA (1997); Franklin E. ZimRIng, The Great AMERICAN Crime DeCline (2007); Fred C. Pampel \& Rosemary Gartner, Age Structure, Socio-Political Institutions, and National Homicide Rates, 11 EUR. Soc. Rev. 243 (1995).

7 See, e.g., Wesley G. Skogan, Citizen Satisfaction with Police Encounters, 8 POLICE Q. 298 (2005); TOM R. TYleR \& YuEN J. Huo, TRUST IN THE LAW: ENCOURAGING PUBlic COOPERATION WITH THE POLICE AND COURTS (2002).

8 See Robert J. Sampson \& Dawn Jeglum-Bartusch, Legal Cynicism and (Subcultural?) Tolerance of Deviance: The Neighborhood Context of Racial Differences, 32 LAW \& Soc'Y REV. 777 (1998); Tom R. Tyler, Public Trust and Confidence in Legal Authorities: What Do Majority and Minority Group Members Want from the Law And Legal Authorities?, 19 BEHAV. SCI. \& L. 215 (2001) [hereinafter Tyler, Public Trust]; Ronald Weitzer, Citizens' Perceptions of Police Misconduct: Race and Neighborhood Context, 16 JUST. Q. 819 (1999). See also Tom R. Tyler \& Jeffrey Fagan, Legitimacy and Cooperation: Why Do People Help the Police Fight Crime in their Communities?, 6 OHIO ST. J. CRIM. LAW 231 (2008). 
detect wrongdoing and protect citizens. Each of these three dimensions intersects with race. ${ }^{9}$ That is, both the disquiet normatively and descriptively, together with the political pressures engendered by crime and its discontents, are focused heavily on the intersection of race and criminal justice. ${ }^{10}$ Racialized policing and racial imbalances in incarceration deepen the racial divide in citizen trust in the law. Rising incarceration rates redistribute public resources to a system widely seen as problematic. Tensions between due process rights and the perceived erosion of personal safety frustrate victims of crime.

Even as crime rates cyclically rise and fall, with high crime sometimes being viewed as a major social problem and sometimes being seen as "under control," the persistence of popular narratives of an unresponsive and oppressive legal system has created a political "space" for significant changes in law and policy, with a steady accretion of power to police and prosecutors. ${ }^{11}$ The changes in law and policy over the past four decades have only worsened the conditions that produce these disparities in perceived legitimacy. ${ }^{12}$ New laws create pressures to contract the schedule of criminal procedural rights for criminal defendants developed by the Warren and Burger Courts nearly four decades ago. The search for drugs has animated policing practices that increase racial disparities in encounters with the police, and also disparities in the ratings and outcomes of those encounters. ${ }^{13}$ In minority communities, these pressures often motivate citizens to withdraw from engagement with the legal system in the co-production of justice and security, while alienation and cynicism give rise to forms of opposition and resistance that further unravel the system's legitimacy. ${ }^{14}$

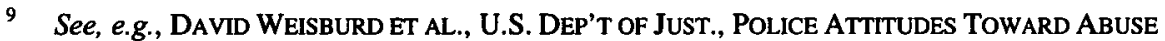
OF Authority: FINDINGS From A NATIONAL STUDY 8-10 (2000), available at http://www.ncjrs.gov/pdffiles1/nij/181312.pdf (showing clear divisions between minority and white officers regarding social norms regarding excessive force and expected sanctions when such violations are uncovered, and that these tensions are felt not only in citizen interactions with legal actors, but also across racial lines within legal institutions). See also Bobo \& Johnson, supra note 1.

10 See GlenN C. LOURY, RACE, InCARCERATION AND AMERICAN VAlUES (2008).

11 See Angela J. Davis, Arbitrary Justice: The Power of the American Prosecutor (2007); Jonathan Simon, Governing Through CrIME (2007); Angela J. Davis, Prosecution and Race: The Power and Privilege of Discretion, 67 FordHAM L. Rev. 13 (1998).

12 See Marc Mauer, Race to Incarcerate (1999); Michael Tonry, Malign NeglectRace, Crime, AND PUnishment In AmERICA (1996); Bobo \& Johnson, supra note 1.

13 See David Cole, No Equal Justice: RaCe and Class In the AMERICAN CRIMINal Justice SYSTEM (2d ed. 2007); David A. Harris, The Stories, the Statistics, and the Law: Why "Driving While Black" Matters, 84 MinN. L. Rev. 265 (1999). See also SAMUEl WALKER, CASSIA SPOHN \& MiRIAM Delone, The Color of Justice: RACE, ETHNICITY AND CRIME IN AMERICA (2d ed. 2000).

14 See Jeffrey Fagan \& Tracey L. Meares, Punishment, Deterrence, and Social Control: The Paradox of Punishment in Minority Communities, 6 OHIO ST. J. CRIM. LAW 173 (2008). See also ELUAH ANDERSON, CODE OF THE STREET: DECENCY, VIOLENCE AND THE MORAL LIFE OF THE INNER City (1999); Patricia Ewick \& Susan S. SIlbey, The Common Place of Law: Stories from EVERYDAY LIFE (1998); Paul Butler, Racially Based Jury Nullification: Black Power in the Criminal Justice System, 105 YALE L. J. 677 (1995); Jeffrey Rosen, One Angry Woman, NEW YoRKER, Feb. 24, 1997 , at 54. 


\section{LEGITIMACY MATTERS}

These challenges to legitimacy raise serious questions not only about the role of criminal law and legal institutions to maintain social norms and express fundamental principles of justice, but also for trust in government more generally. The challenges to legitimacy have important implications for the viability of the law and the legal system. First, people who view the law as illegitimate are less likely to obey it, ${ }^{15}$ and people who view police officers and judges as lacking in legitimacy are less likely to follow their directives. ${ }^{16}$ Although the law is based on the implicit or explicit threat of sanctioning for wrongdoing, the legal system depends heavily on voluntary compliance from most citizens. Hence, lower levels of legitimacy make social regulation more costly and difficult. So, legitimacy is both a social and a political good. As Professor Solum notes, "[a] society in which citizens can reasonably regard themselves as having $a[n]$. . . obligation to obey the law is better than a society in which the law begins with a presumption of illegitimacy."17

Second, the police depend heavily on the voluntary cooperation of citizens to fight crime. Citizens report crime and criminals, informally help to police their neighborhoods, and aid the courts as jurors and witnesses. Without these cooperative acts from the public, the police would have greater difficulty maintaining civil order. Accordingly, society has a lot to lose when the public loses confidence in the legal system: challenges to legitimacy raise important questions about the ability of criminal law and legal institutions to maintain social norms and social order, and to express fundamental principles of justice.

\section{A. Sources of Legitimacy}

The legitimacy of the criminal law is enhanced when its legal actors and institutions act in ways that citizens perceive as consistent with popular principles of procedural fairness, security and proportionality, ${ }^{18}$ and that resonate with the interests of political elites who influence the institutions of criminal justice. ${ }^{19}$ So, understanding how legitimacy of criminal legal institutions is created and

15 See Tom Tyler, Why People Obey the LaW (2d ed. 2006) [hereinafter Tyler, Obey].

16 Lawrence B. Solum, Procedural Justice, 78 S. CAL. L. REV. 181, 277 (2004) (noting that citizens may feel no political, social or moral obligation to obey laws when there are disagreements about the justice or goodness of particular laws). See also TYLER \& HUO, supra note 7; Tyler \& Fagan, supra note 8 .

17 Solum, supra note 16, at 278.

18 See TYLER, OBEY, supra note 15. See also Jeffrey Fagan \& Tom Tyler, Legal Socialization of Children and Adolescents, 18 Soc. JusT. RES. 217 (2005); Tracey L. Meares, Norms, Legitimacy, and Law Enforcement, 79 OR. L. REv. 391 (2000) [hereinafter Meares, Norms]; Jason Sunshine \& Tom R. Tyler, The Role of Procedural Justice and Legitimacy in Shaping Public Support for Policing, 37 LAW \& SOC'Y REv. 513 (2003). 
maintained requires attention to the actions and perspectives of the public, the police, and elites. Public lack of trust and confidence in the police, especially among racial minorities, is the most obvious source of felt illegitimacy. There are longstanding grievances between minority citizens and the police that give rise to anger and suspicion on the one hand, ${ }^{20}$ and ambivalence on the other. ${ }^{21}$ Elites define the problem of crime and the general approach that is taken to dealing with crime. They leverage public opinion to support strategies such as focusing on minor lifestyle offenses as the key to preventing serious crime. By defining the manner in which the problem of crime and crime prevention is conceptualized, elites define the framework within which issues of legitimacy emerge, and where the allocation of legitimacy costs is determined. ${ }^{22}$

These three dimensions are mutually influential and reinforcing. For example, police culture may emphasize an authoritarian style of police behavior. This may be interpreted by residents of a heavily policed neighborhood as a reflection of police racism, and trust and confidence in the police may decline there, especially if this takes place in a minority community. ${ }^{23}$ As trust and confidence declines, law-breaking may rise, and cooperation with the police may decline. Seeing a crime wave, elites may call for further shows of force by the police. In this case, the three aspects of legitimacy would be interacting to produce a spiral of declining legitimacy. In other cases, they might act to mitigate each other. Elites might recognize declining trust and confidence and advocate policies of community policing or community involvement in the definition of community problems. These policies could act to reverse declining trust and confidence by leading to changes in police culture and policing behavior. In either case, these dynamics would illustrate the interrelationship among the three aspects of legitimacy creation.

\section{Procedural Concerns}

Throughout the last several decades, problems in procedural justice have been evident in the strained relationships between citizens and police in many communities. These strains are felt most heavily in minority communities, where a cluster of racialized problems has eroded trust between citizens and law. These

20 See Fagan \& Meares, supra note 14. See also WEITZER \& TUCH, supra note 1. For an historical example, see THE KERNER REPORT, supra note 3.

21 See Tracey L. Meares, Social Organization and Drug Law Enforcement, 35 AM. CRIM. L. REV. 191 (1998) [hereinafter Meares, Social Organization]; Tracey L. Meares, Charting Race and Class Differences in Attitudes Toward Drug Legalization and Law Enforcement: Lessons For Federal Criminal Law, 1 BUFF. CRIM. L. REV. 137 (1997) [hereinafter Meares, Charting Race].

22 See Bernard E. Harcourt, Illusion of Order: The false Promise of Broken Windows POLICING (2001).

23 See Fagan \& Meares, supra note 13. See also WeITZER \& TuCH, supra note 1. 
problems include racial profiling in the streets and on the highways, ${ }^{24}$ excessive force, especially against minority citizens, ${ }^{25}$ and drug law enforcement policies that have stigmatized predominantly minority communities with saturated enforcement. $^{26}$ A series of notorious incidents involving police assaults and shootings of minority suspects have negated the heightened legitimacy that had accrued from declining crime rates. ${ }^{27}$ These issues all speak to the normative standards that ought to govern police conduct and the degree to which those standards are being met.

In addition, it is no secret that while minority and white citizens both lack confidence in the criminal justice system, the level of distrust is higher among black citizens. ${ }^{28}$ Procedural concerns about policing and police activities extend well beyond minority communities, and are felt by all citizens in their everyday interactions with law and legal institutions. ${ }^{29}$

In the nearly invisible daily administrative or substantive interactions of citizens with the law, citizens often experience strict adherence by legal actors to procedural details of rules and definitions as a lack of empathy. These interactions generate opposition and resistance to social and moral norms, not compliance. When law is intransigently normative, law and legal actors often worsen the problems they are supposed to solve, and the opposition that develops often translates into alternative codes or competing social norms. ${ }^{30}$ This occurs because legal authorities lack an awareness of and sensitivity to the issues that define justice from the public's point of view.

Social class and race also mediate the extent of collateral consequences from procedural concerns. Professors Susan Silbey and Patricia Ewick show how access to the law and the responsiveness of legal actors are poorer for those with fewer resources. ${ }^{31}$ For example, such problems arose in the enforcement of domestic violence laws, the social position and political resources of (mostly white) feminists helped translate their opposition into substantive and procedural legal reform. ${ }^{32}$

24 See COlE, supra note 13; RANDAll KenNEDY, RaCe, CRIME AND THE LAW (1997); Harris, supra note 13.

25 See Jerome H. SKolnick \& JAMES J. FyFe, ABove the LAW: POLICE AND tHE EXCESSIVE USE OF FORCE (1993).

26 See Meares, Social Organization, supra note 21; William J. Stuntz, Race, Class and Drugs, 98 CoLUM. L. REv. 1795 (1998).

27 See Fagan \& Meares, supra note 14.

28 See Sampson \& Jeglum-Bartusch, supra note 8; Meares, Charting Race, supra note 21; Stuntz, supra note 26; SOURCEBOOK OF CRIMINAL JUSTICE STATISTICS, supra note 2.

29 See TYLER \& HUO, supra note 7; Fagan \& Meares, supra note 14.

30 See Jeffrey Fagan, Context and Culpability in Adolescent Crime, 6 VA. J. SoC. POL'Y \& L. 507 (1999) [hereinafter Fagan, Context and Culpability].

31 See EWICK \& SILBEY, supra note 14.

32 See Jeffrey Fagan, The Criminalization of Domestic Violence: Promises and Limits, Presentation at the 1995 Conference on Criminal Justice Research and Evaluation (July 10, 1995), 
Procedural concerns are important because studies of the foundations of legitimacy demonstrate the members of the public evaluate the legitimacy of the law and of legal authorities through judgments about the legitimacy of legal procedures. ${ }^{33}$ This is true of both members of the white and the minority communities. ${ }^{34}$

These legitimacy judgments are important because they shape both people's willingness to accept the decisions of legal authorities and their everyday obedience to the law. ${ }^{35}$ For example, in a study of Whites, African Americans, and Hispanics, Tom Tyler and Yuen Huo found that the primary factor shaping the willingness to voluntarily accept the decisions of police officers and judges was the judgment that the decisions were fairly made. There were two key components of fairness: (1) neutrality (lack of bias, factuality) and (2) respectful treatment that recognizes citizen rights and treats people with dignity. ${ }^{36}$ These two elements of fair treatment led citizens to trust the motives of legal authorities to be benevolent. If citizens thought that fair procedures had been used, they deferred to the decisions of legal authorities.

Although a central function of the police and the courts is to protect the members of the public from crime, the public does not evaluate legal authorities primarily via their success or failure in this effort. On the contrary, the key antecedent of confidence is the public judgment that the police and courts exercise their authority through fair procedures. ${ }^{37}$ For example, even in high-crime areas, people's confidence in the police is more strongly linked to whether they feel that the police harass and demean citizens than it is to whether the efforts of the police are lowering crime. As a result, the police can be effective in lowering crime but can do so in ways that alienate the public and damage the legitimacy of the law.

\section{Distributive Justice}

A second crisis of legitimacy arises in perceptions of distributive justice, or the proportionality and consistency of legal responses to condemnable behaviors. For the law to be perceived as morally credible, it should punish those who deserve it, protect those who do not, and allocate punishments in proportion to the

\footnotetext{
in NAT'L INST. OF JUST. RES. REP., Jan. 1996, available at http://www.ncjrs.gov/pdffiles/crimdom.pdf. See also David L. Faigman, To Have and Have Not: Assessing the Value of Social Science to the Law as Science and Policy, 38 EMORY L. J. 1005 (1989).

33 See Tyler, ObeY, supra note 15; TOM R. TYLER ET AL., SOCIAL Justice In A Diverse SOCIETY (1997).

34 See TYLER \& HUO, supra note 7.

35 See id.; TYLER, OBEY, supra note 15.

36 See TYLER \& HUO, supra note 7.

37 See, e.g., Tyler, Public Trust, supra note 8.
} 
perceived harm. ${ }^{38}$ This is a two-sided argument, where strong enforcement of laws that the community greets with ambivalence can erode legitimacy. Underenforcement for acts that are widely viewed as deserving punishment damages legitimacy, as well. Distributive justice concerns also damage legitimacy when there is (perceived) asymmetry between the harm of the act and the severity of the punishment. A gap between community sentiments about wrongdoing and the enforcement of the criminal law can reduce internal incentives to comply with that law. When laws punish behaviors disproportionately to their perceived severity, it lowers the legitimacy of the law.

A critique of the leniency of the criminal law fuels legitimacy concerns. Efforts to limit prisoner appeals in death penalty cases are an expression of citizen frustration with legal impediments to distributive justice in egregious and highly emotional cases. ${ }^{39}$ Sentencing reforms that limit judicial discretion reflect critiques both of disparate and lenient sentencing, ${ }^{40}$ and reflect the tension between the demands for substantive punishment and the ideals of an independent judiciary. ${ }^{41}$ Tensions between procedural rights and the intractability of crime problems affecting poor neighborhoods have given rise to new laws that expand the discretion of police to selectively criminalize both the (behavioral and semiotic) correlates of criminality as well as crimes themselves. ${ }^{42}$

The second aspect of distributive justice is the equal application of the law. If people feel that the legal system does not apply justice consistently across people and groups, this also undermines legitimacy. Professor Austin Sarat suggests:

[the] perception of unequal treatment is the single most important source of popular dissatisfaction with the American legal system. According to available survey evidence, Americans believe that the ideal of equal protection, which epitomizes what they find most valuable in their legal system, is betrayed by police, lawyers, judges, and other legal authorities. ${ }^{43}$

38 See TYleR ET AL., supra note 33; Paul H. Robinson \& John M. Darley, The Utility of Desert, 91 Nw. U. L. REv. 453 (1997).

39 See Samuel H. Pillsbury, Judging Evil: Rethinking the Law of Murder and MANSLAUGHTER (2000).

40 See TONRY, supra note 12.

41 One of the early critiques of indeterminate sentencing came from prisoner advocates, who cited disparate and subjective decisions by correctional authorities that extended incarceration periods for prisoners who failed to show behavioral signs of progress. See, e.g., MARVIN E. FrankEL, CRIMINAL SENTENCES: LAW WITHOUT ORDER (1974).

42 See Tracey L. Meares \& Dan M. Kahan, Law and (Norms of) Order in the Inner City, 32 LAW \& SOC'Y REV. 805 (1998).

43 Austin Sarat, Studying American Legal Culture: An Assessment of Survey Evidence, 37 LAW \& SOC'Y REV. 427, 434 (1977). 
Here the focus is not on whether outcomes are appropriate to the level of the crimes, but on whether those outcomes, whatever they are, are consistently applied to everyone. When outcomes are applied disproportionately or inconsistently it produces a form of disrespect that gives way in some quarters to resistance. ${ }^{44}$

The legitimacy of the criminal justice system has been questioned from each of these perspectives. In some communities, punishment has become common, losing both its contingent value as a deterrent and its (moral) claim of fairness and proportionality. ${ }^{45}$ The high rates of incarceration of drug offenders in the U.S. have fueled the growth in prison populations ${ }^{46}$ and the disjuncture between the severity of many drug crimes and the harsh punishment they carry undermines the legitimacy of the law. ${ }^{47}$ Professor Daniel Nagin suggests that high and noncontingent incarceration rates produce "stigma erosion," where punishment becomes morally and socially meaningless and oppressive. The deterrent effects of punishment decline the more often it is imposed. ${ }^{48}$

This domain of legitimacy also has become racialized. Drug law enforcement has produced racial disparities both in the intensity and tone of enforcement ${ }^{49}$ and in incarceration rates. ${ }^{50}$ Egregious disparities in sentencing for crack versus powder cocaine reflect racial differences in the patterns of sale and use, aggravating the racialized bitterness about this expression of the illegitimacy of the criminal law. ${ }^{51}$ These perceptions in Black communities seem to underlie expressions of resistance and opposition by jury nullification. ${ }^{52}$

\section{Crime Control Efficacy}

Rising crime rates have fueled a recurring cycle of crises about the efficacy and legitimacy of the criminal law and the criminal justice system. Professor David Garland discusses how a "culture" of punitiveness has grown both in law and legal institutions in the United States (and the United Kingdom) in the past

44 See ANDERSON, supra note 14. See also Fagan, Context and Culpability, supra note 30.

45 See Fagan \& Meares, supra note 14.

46 See Alfred Blumstein \& Allen J. Beck, Population Growth in U.S. Prisons, 1980-1996, in PRISONS 17 (Michael Tonry \& Joan Petersilia eds., 1999). See also BruCE WeSTERN, PUNISHMENT AND INEQUALITY IN AMERICA (2006).

47 See Stuntz, supra note 26.

48 Daniel Nagin, Criminal Deterrence Research at the Outset of the Twenty-First Century, 23 CRIME \& JUST. 1 (1998).

49 See Meares, Norms, supra note 18.

50 See William J. Stuntz, The Pathological Politics of Criminal Law, 100 MiCH. L. REv. 505 (2001); Stuntz, supra note 26. See also David A. Sklansky, Cocaine, Race and Equal Protection, 47 STAN. L. REV. 1283 (1995).

51 See TONRY, supra note 12; KENNEDY, supra note 24.

52 See Rosen, supra note 14; Butler, supra note 14. 
quarter century, an adaptation and response to the persistence of high crime rates. ${ }^{53}$ The stability of these popular notions in the United States during the current period of declining crime rates is evidence of the depth of the cultural shift. According to Garland, these popular normative shifts have pervaded both law and legal institutions, and explain the current presumption of punishment that has replaced the older culture of "penal welfare" that was the common language of legal actors for decades. These developments reflect popular concerns about the legitimacy of legal institutions not only to control crime but also to mete out proportionate punishment.

The expressions of this cultural or normative shift in law and policy reflect the crisis of legitimacy. These are important changes in substantive and procedural law that may have profound consequences, for once in place, they are difficult to undo. Developments such as the spread of mandatory sentencing and the narrowing of judicial discretion may fundamentally alter the balance of powers in the administration of justice. For example, there has been a steady process of lowering the threshold for transferring adolescents from the juvenile to the criminal court, a reflection of broader concerns for proportionate punishment of juveniles and lowered confidence that judges will make decisions consistent with these popular demands. ${ }^{54}$

It is unlikely that these laws will be reversed, no matter what their substantive implications for crime control. But such laws also lead to dissensus among legal actors and give rise to forms of organizational opposition that intensify legitimacy concerns both within and outside the law. For example, judges have recreated juvenile courts within the criminal court to maintain broader social norms about crimes by children, in effect subverting the goals of transfer laws. In drug law sentencing, opposition from judges to sentencing requirements has raised tensions between the competing norms of judicial independence and popular demands for stiffer punishment. ${ }^{55}$

Similarly, the shift in discretion to prosecutors in several arenas potentially alters basic constitutional arrangements for power. The imposition of mandatory arrest statutes and policies in cases of domestic violence has been subverted by the filing of mutual complaints by two parties, further undermining the perceived legitimacy of the criminal law among advocates who sought protection. When legal formalism has counterproductive effects, as was the case in mandatory arrest for domestic violence, legitimacy concerns are given more traction and weight. ${ }^{56}$

53 See David Garland, The Culture of Control: Crime and Social Order in CONTEMPORARY SOCIETY (2001).

54 See Jeffrey Fagan \& Franklin E. Zimring, Introduction to THE CHANGING Borders of JuVENILE Justice: Transfer of AdOLESCENTS TO THE CRIMINAL COURT 1 (Jeffrey Fagan \& Franklin E. Zimring eds., 2000).

55 Kate Stith \& Jose A. Cabranes, Fear of Judging: Sentencing Guidelines In The FEDERAL COURTS (1998).

56 Fagan, supra note 32. 
Concerns over the efficacy of laws and legal institutions to protect citizens also is evident in secular developments such as the growth in private policing, the design of walled and gated communities reflecting security concerns, and a wide range of zero-tolerance laws and policies that reject the ideals of informal social control and the prospects of developmental or behavioral change. Gated communities are an important illustration of the replacement by those communities of broader legal norms with localized codes of conduct and a strong desire for exclusivity and protection that the criminal law is unable to provide. ${ }^{57}$

Doubts about the popular legitimacy of the criminal justice system have given rise to "community justice" mechanisms, a positive development arising from the crisis of legitimacy. Based on sociological and social psychological theory, one could argue, for example, that the criminal law is seen as legitimate when citizens participate as clients, overseers, and participants in the production of justice. ${ }^{58}$ This regulatory function influences not only the conduct of the institution, but also its perception by others coming into contact with it. How the consensus is achieved regarding the goals and optimal behavior of the institution is a complex process of social interaction between legal and extra-legal actors. Both the substantive outcome of those interactions in terms of procedural and distributive justice, and the outcomes in terms of new ways for citizens to participate in the production of justice, can neutralize if not overcome the legitimacy crises that arise from the isolation of law from citizens.

\section{B. Theorizing Legitimacy}

Legitimacy is a concept that is important in a number of fields in the social sciences. Yet, we do not have a good theory that spans across literatures. The development of theory and locating its convergence in issues of the criminal law is one of the central tasks of the authors in this Symposium. We have assembled a cross-disciplinary group to focus on this issue. To date, legal theory has paid the most attention to this issue, and its lessons have provided a good starting point for the scholarship in this Symposium.

The criminal law serves several functions that are central to maintaining social order. First, it facilitates the creation and maintenance of a social consensus that is necessary for sustaining moral norms about behaviors that are condemnable. ${ }^{59}$ Second, the criminal law is integral in gaining compliance of citizens toward these moral norms, compliance that produces security. ${ }^{60}$ If the law

57 Mark H. Moore, Notable Speech: Legitimizing Criminal Justice Policies and Practices, FBI LAW ENFORCEMENT BULL., Oct. 1997, available at http://www.fbi.gov/publications/leb/1997/oct973.htm [hereinafter Moore, Legitimizing]. See also Mark H. MoOre, Creating Public Value: Strategic Management In Government (1995).

58 See Meares, Norms, supra note 18.

59 See Robinson \& Darley, supra note 38.

60 See Moore, Legitimizing, supra note 57. 
is perceived as a reliable expression of these norms, citizens are more likely to defer to the moral authority underlying its proscriptions. Third, the law is necessary to produce justice. Its moral authority is reinforced when its application is seen as just and fair, by both the victims of crime and those who are punished. ${ }^{61}$ Thus, the legitimacy and effectiveness of the law-especially the criminal laware both heavily dependent on the moral credibility it has achieved in the eyes of citizens. $^{62}$ A key motivation for obeying the law is normative or ethical-that people feel it is the right thing to do.

Recent discussions of the legal system emphasize the centrality of such ethical/normative motivations to the ability of the legal system to effectively secure compliance. Although the risks of being caught and punished for wrongdoing can shape people's law-related behavior, ${ }^{63}$ such effects are small in magnitude. For example, Professor Robert MacCoun estimates that the likelihood or severity of expected punishment for using drugs is a very limited predictor of drug use $^{64}$ Hence, deterrence alone is a relatively ineffective means for maintaining social order. The law needs to have legitimacy to provide an alternative motivation for compliance. Further, as already noted, such normative/ethical motivations are especially valuable because they involve selfregulation. Citizens take the responsibility to follow rules onto themselves and do not need to be induced to follow the law through threats of punishment. To the degree that citizens comply with the law because they view it as legitimate, the task of legal authorities is easier, and societal resources can be deployed to other activities, such as education or health care.

The legitimacy of the criminal law is enhanced when its legal actors and institutions act in ways that citizens perceive as consistent with popular principles of procedural fairness, security and proportionality. Their interactions in each of these domains are important factors in shaping whether and how the norms of the criminal law are internalized into individuals' behavioral codes. What citizens see and experience through interactions with police, courts and other legal actors subtly shapes their perceptions of the legitimacy of the relation between individuals and society. These experiences influence the development of their notions of the moral basis of the law, rules, and agreements among members of society, and the legitimacy of authority to deal fairly with citizens who violate society's rules, and to protect those who are victims of legal transgressions. When legal institutions and actors fail to achieve any of these three dimensions of legitimacy, the moral foundations of both the law and its institutions are suspect.

This is the current crisis of the criminal justice system. From several perspectives, the difficulties of the criminal law to achieve these functions

61 See TYLER, OBEY, supra note 15.

62 See Robinson \& Darley, supra note 38.

63 See Nagin, supra note 48.

64 See Robert J. MacCoun, Drugs and the Law: A Psychological Analysis of Drug Prohibition, 113 PsYCHOL. BULL. 497 (1993). 
undermines the legitimacy not only of the law but also of the legal institutions that enforce it. Professor Mark Moore suggests that the current challenge to the legitimacy of the criminal justice system is whether it can achieve technical proficiency (security, proportionality) while remaining "aligned with important legal virtues, such as [procedural] fairness and restraint." legitimacy has suffered as the legal system struggles to achieve each of these three goals.

One of the challenges in this Symposium is to capture these processes in a conceptual framework that reflects the dynamics of interaction between citizens, law and legal institutions. Beyond legal philosophy, legitimacy is a concept that is important in a number of fields in the social sciences. Yet, we do not have a good theory that spans across law, political theory, or other literatures. Theoretical development and an accompanying research agenda is an important foundational and preceding task.

\section{Legitimacy and Criminal Law}

The legitimacy of the criminal law and legal institutions is a function of its moral credibility. Legitimacy is directly related to the deference of individuals both to its social norms, and to the participation of citizens in the co-production of security. It derives not just from achieving the instrumental goals of crime control, but also from two dimensions of justice that reflect core values of American society: fair treatment and proportional outcomes. The crises of legitimacy over the past thirty years reflect the erosion of public confidence on each of these dimensions. Restoring legitimacy therefore has both instrumental value for crime control, and political importance for sustaining citizen participation in social control.

How legal actors and laws earn credibility is the policy question that flows from this understanding. There are several components to this question. First, what processes produce credibility? The experiences of the Ten Point Coalition ${ }^{66}$ illustrate how new forms of "deliberative democracy" can infuse the criminal law with credibility or legitimacy. Along similar lines, anti-gang and anti-narcotics loitering ordinances have been passed in Chicago that specifically provide citizens with opportunities to direct law enforcement resources towards community problem areas in ways that, in effect, constrain police discretion and thus enhance accountability and legitimacy. ${ }^{67}$ Community prosecution, therapeutic jurisprudence, and other emerging forms of interaction between citizens and legal actors may offer the same promise of instantiating credibility into legal institutions.

65 See Moore, Legitimizing, supra note 57.

66 See Anthony A. Braga et al., Losing Faith? Police, Black Churches, and the Resurgence of Youth Violence in Boston, 6 OHI ST. J. CRIM L. 141 (2008); Christopher Winship \& Jenny Berrien, Boston Cops and Black Churches, 136 PUB. INT. 52 (1999).

67 See Meares, Norms, supra note 18. 
An important lesson of these efforts is the bi-level nature of the process, where legitimacy aggregates from a pattern of interactions in individual cases, but also flows from the organizational arrangements between citizens and law that these interactions require.

Second, building the legitimacy of legal processes requires that actors with moral authority be part of the process. Whether this can obtain from actions solely of legal actors, or whether it requires interactions with the citizens or groups who themselves have moral standing, is an empirical and policy question for study and experimentation. This is especially critical when legitimacy concerns reflect racial divides, and when the concerns of different racial groups may conflict. The lessons of the "community justice" programs of the past decade are important case studies of efforts to build legitimacy through processual dynamics. ${ }^{68}$ We also see these lessons from domains beyond the criminal law, such as the complex organizational interactions around resolution of workplace conflicts over discrimination or sexual harassment, ${ }^{69}$ where interactions across both vertical and horizontal boundaries within organizations produced a consensus on the legitimacy of new rules to resolve bitter conflicts. Or, as Moore suggests, legitimacy is the product of enhancing popular and moral credibility while maintaining both technical proficiency and pursuing the ideals of fairness and procedural restraint. ${ }^{70}$

Third, both procedure and outcome are components of legitimacy, and deficits in either area can weaken popular legitimacy. The importance of the quality of (procedural) interactions has been shown in numerous studies, including Tyler's research with Chicago citizens. ${ }^{71}$ But many of the legitimacy-based attacks on the criminal law reflect concerns with substantive outcomes, including both distributive justice and security concerns. Garland's assessment of cultural shifts flowing from legitimacy concerns shows the importance of the momentum of moral concerns, even in light of statistics showing that many of these problems have been remedied. Accordingly, both these dimensions are likely to be needed in an effort to build legitimacy. One goal for the Symposium authors is to explore the procedural and substantive underpinnings of legitimacy.

From the perspective of either type of legitimacy, fashioning structures that communicate the reality of legitimacy concerns in the criminal law and that themselves launch new forms of interaction between citizens and legal actors are potentially important means of building legitimacy. Hence, an understanding of the nature of legitimacy is central to addressing problems in criminal justice. For example, if substantive concerns are central to legitimacy, then maintaining

68 See DAVID R. KARP, COMMUNITY JUSTICE: AN EMERGING FIELD (1998).

69 See Susan Sturm, Second Generation Employment Discrimination: A Structural Approach, 101 Colum. L. Rev. 458 (2001).

70 See Moore, Legitimizing, supra note 57; see also George L. Kelling \& Mark H. Moore, The Evolving Strategy of Policing, in CoMmunITY Policing: ClassiCal READINGS 96 (Willard M. Oliver ed., 1999).

71 See TYLER, OBEY, supra note 15. 
legitimacy requires the ability to address social problems such as crime. If procedural issues are key, then attention needs to be focused on the way that the police and courts function both as institutions, and as individual actors.

\section{THE SYMPOSIUM}

The collection of articles in this Symposium reveals the complex ways in which the everyday interactions between citizens and criminal justice institutions can either produce or corrode legitimacy, and with what effects on the coproduction of security. The articles trace-from political economy to the diverse interests of communities, legal actors and elites-the concrete ways in which institutional preferences and policies shape how citizens attribute legitimacy to the law and its agents, and the consequences of those attributions. The Symposium authors suggest that legal actors, whether autonomously or in complex interactions with community, are morally and ethically responsible for the legitimation of their institutions and the social rules and laws they enforce. These three articles also demonstrate, in practical and concrete analyses, how our collective understanding of legitimacy requires that we seek to turn criminal justice system actors away from what Andrew Taslitz describes as the "false messiah of racial blindness,"72 toward a more conscious understanding of the implications of criminal justice policy for the engagement of marginalized racial and ethnic communities in the difficult task of the production of security.

The Symposium suggests the need for careful analyses of the origins of legitimacy in criminal justice, and for a more complete understanding of the role of legitimacy in the production of justice and security. Building upon the common themes of community, justice and legitimacy, the Symposium articles examine how legitimacy arises within a context of community values and institutions, and how institutional influences and interests both in community and criminal justice reinforce or undermine legitimacy. Each of the articles examines, from unique perspectives, how interactions between the local community and the goals and values of dominant institutions and actors are expressed in the policies and practices of the police within particular communities. Each argues that legitimacy is inevitably a product of local institutions and cultures, and that the effective development and maintenance of legitimacy requires the police to understand and respond to the concerns and values of the people within those local communities.

New forms of interaction between citizens and legal institutions have altered power-sharing arrangements with the goal of increasing the legitimacy of the criminal law. But both institutional and political forces can destabilize these arrangements, raising questions about whether they are sustainable in changing organizations and political cultures. Anthony Braga, David Hureau and Christopher Winship show that coalitions such as the Ten Point Coalition in

72 Andrew E. Taslitz, Racial Blindsight: The Absurdity of Color-Blind Criminal Justice, 5 OHIO ST. J. CRIM. L. 1, 4 (2007). 
Boston, which exemplify the "mediating institutions" that involve citizens and legal actors in the co-production of security, are challenged to sustain their influence as the institutional arrangements and contexts change. These arrangements are inherently fragile and consume both political capital and tangible resources. Both internal organizational change and the inherent complexity of collaboration challenge innovation, and when legal actors collaborate with community institutions, the challenges multiply. Not only do assets and capabilities vary across organizations, but so too do incentives and the animating ideologies of each participating entity. The development of common language and norms is acutely challenged in the high stakes setting of crime and violence, when risks are pervasive.

The Symposium also creates an opportunity to construct and articulate a framework for the study of the legitimacy of criminal law and legal institutions. So, for example, the structural aspects of the law, including both incentivized enforcement policies and sentencing laws, can induce tensions between citizens and law that deracinate legitimacy. The impacts of these structural features of criminal justice are skewed toward poorer communities, where crime and poverty intersect, where enforcement is concentrated, and where political and economic influence over policy is inherently weak. Legitimacy of the criminal law and its institutions is weakest in these communities, suggesting that there are social ecological dimensions that explain variations in legitimacy and residents' ties to the law. ${ }^{73}$ Tracey Meares and I explore the intersection of community social position and law to theorize how legitimacy accrues or dissipates in poor places, and how it influences the relationships of individuals and communities to law and social control. In communities where both enforcement and crime are concentrated, the recurring interactions of citizens and police, and the reach of criminal law into tightly woven social networks of residents, engenders popular dissatisfaction based on the interactions of residents with law and legal actors. But these also are places where economic life is fragile and unstable, and where residents' stakes in conformity ${ }^{74}$ and compliance are discounted by the stresses of poverty. We show, through a review of empirical research crime and community, that both the normative bases - the moral legitimacy - and the utilitarian functions of punishment are compromised when the social and cultural distance between punishers and the punished widens. The reciprocity between social and legal controls is strained when both economic and social life are fragmented, and when punishments are so common as to lose their contingent value and expressive meaning. To restore and strengthen legitimacy in criminal law and criminal justice, we call for a reconfiguration of criminal justice along lines of reintegrative justice, substantive rationality, and proportional and procedural fairness.

73 See, e.g., Sampson \& Jeglum-Bartusch, supra note 8.

74 Jackson Toby, Social Disorganization and Stake in Conformity: Complementary Factors in the Predatory Behavior of Hoodlums, 48 J. CRIM. L., CRIMINOLOGY \& POLICE SCI. 12 (1957). 
Legitimacy is not simply an abstraction or a sentiment, but an internalized obligation to defer to decisions of legal authorities. ${ }^{75}$ Because it instantiates within the individual the moral and social norms of law, the erosion of legitimacy has behavioral consequences: withdrawal of cooperation with authorities, and defiance and rejection of legal and social norms. ${ }^{76}$ Discussions of legitimacy often overlook the fact that this obligation and norm is in part the product of interactions with legal actors and authorities. The evaluations of the exercise of legal authority shape perceptions and evaluations of its legitimacy. In other words, legitimacy for most people is the aggregation of their experiences or the experiences of those around them, and the emotions they generate. Tom Tyler and I use survey data to show that attributions of the legitimacy of law social norms are linked to assessments of the justice of the procedures used by the police to exercise their authority and that legitimacy in turn shapes compliance and cooperation with the law. Because the long-term effectiveness of law requires that citizens perceive its legitimacy, deficits in legitimacy threaten to undermine security by undermining attachments between citizens, law, and legal institutions.

\section{CONCLUSION}

The Symposium advances scholarly interest in legitimacy from political theory to the norms, policies and practices of criminal justice. The articles locate legitimacy in the contexts where the criminal law most poignantly and intensively intervenes in the lives of citizens, both those who break the law and those who uphold it. These contributions identify the institutional arrangements and legal regimes that perpetuate deficits in legitimacy. Each group of authors invoke three perspectives to assess legitimacy within the criminal legal system: procedural justice, institutional preferences and arrangements, and the social contexts of interactions with criminal justice authorities. In so doing, the Symposium confronts the racial dimensions of police-citizen interactions from both normative and consequentialist perspectives.

The Symposium authors consider these issues along two dimensions. One is normative, and considers the standards that the legal system should meet. The other is sociological and social psychological: it examines what people care about

75 BEETHAM, supra note 19 , at 18 ("[L]egitimacy involves the demonstrable expression of consent on the part of the subordinate to the particular power relation in which they are involved, through actions which provide evidence of consent."). But see also MAX WEBER, ECONOMY AND SOCIETY: AN OUTLINE OF INTERPRETIVE SOCIOLOGY 212-16 (Guenther Roth \& Claus Wittich eds., U. of Cal. Press 1978) (1968) (discussing legitimation of state power based on individuals' acceptance of and submission to that power and arguing for the value to the state of being viewed as legitimate among the populace).

76 TYLER \& HUO, supra note 7, at 7 (advocating a "process-based model of regulation that encourages voluntary deference" to authorities based on faimess in exercise of authority); TYLER, OBEY, supra note 15, at 23-30 (summarizing past studies suggesting that legitimacy exists when society internalizes normative reasons for voluntarily obeying the commands of authorities). 
and react to in their everyday interactions with the police and the courts. The articles focus not only on elite discourse about what the law and legal authorities should do, or the standards to which these authorities should be held. The Symposium authors are also concerned about what people in the community care about, how they experience law, and what they define as important in their evaluations of the legal system. This effort builds upward from the human concerns the shape people's reactions to the police, the courts, and the law. It does so by drawing on the results of empirical findings about the psychology of reactions to social regulatory activities. And it incorporates perspectives on the institutions that are available to translate normative values to psychological perceptions and ties to the law. In this respect, we hope, this Symposium helps to shed new light on a recurring American criminal justice problem. 